\title{
Research on Economic and Trade Cooperation Problems and Countermeasures between China and Turkmenistan
}

\author{
Kovus Ovezdyrdyyev, Baoming Zhang \\ Business School, University of Shanghai for Science and Technology, Shanghai, China \\ Email:2282316031@qq.com
}

How to cite this paper: Ovezdyrdyyev, K. and Zhang, B.M. (2020) Research on Economic and Trade Cooperation Problems and Countermeasures between China and Turkmenistan. Open Journal of Business and Management, 8, 357-368.

https://doi.org/10.4236/ojbm.2020.81022

Received: December 31, 2019

Accepted: January 13, 2020

Published: January 16, 2020

Copyright (c) 2020 by author(s) and Scientific Research Publishing Inc. This work is licensed under the Creative Commons Attribution International License (CC BY 4.0).

http://creativecommons.org/licenses/by/4.0/

\begin{abstract}
Since the establishment of diplomatic relations between China and Turkmenistan in 1992, the two countries have made remarkable achievements in economic cooperation. Especially after the "one belt and one way" strategy was put forward, the economic and trade cooperation between China and the mainland was given new significance of the times. In this context, this paper makes an in-depth study of China Turkmenistan economic and trade cooperation. This paper first briefly introduces the economic development of Turkmenistan, then summarizes the history and current situation of economic and trade cooperation between China and Turkmenistan, and focuses on natural gas as a case study. Next, it analyzes the advantages and disadvantages of the economic and trade cooperation between China and Turkmenistan, and puts forward the countermeasures. Finally, the prospect of future economic and trade cooperation between China and Turkmenistan is given.
\end{abstract}

\section{Keywords}

China, Turkmenistan, Economic and Trade Relations, Prospect

\section{Introduction}

Since the reform and opening-up, China's foreign trade has developed rapidly and has become one of the countries with great influence in the world market. Turkmenistan, a central Asian country, is close to China in its geographical position. As a friendly neighbor of China, Turkmenistan must be one of China's partners in economic cooperation. The two countries have strong economic complementarity, vigorous trade exchanges and great potential for cooperation. The friendly relations between China and Turkmenistan have started from a 
long time ago. As early as 2000 years ago, the two countries were closely linked because of the ancient Silk Road. Therefore, the mutually beneficial cooperative partnership between the two countries has a profound historical basis [1]. In this context, the economic and trade relations between China and Turkmenistan are worthy of in-depth study, and both peoples will benefit from this kind of economic cooperation.

In this article, the author will make an in-depth study of the economic and trade cooperation between China and Turkmenistan, find out the potential problems and obstacles in the cooperation through the analysis of the current situation of the economic and trade cooperation between China and Turkmenistan in the fields of natural gas, oil and gas, and put forward suggestions and prospects for the future economic and trade cooperation between the two countries, so as to maximize the potential of economic and trade cooperation between the two countries and greatly increase the economic benefits from cooperation.

\section{Research Status}

More and more scholars at home and abroad began to study the economic and trade cooperation between China and Turkmenistan, and many high-quality research results emerged. Zhao Qingsong (2013) divided the development process of China Turkmenistan trade into several stages in the history, current situation and Prospect of economic and trade cooperation between China and Turkmenistan, and focused on the analysis of the achievements and characteristics of each stage. The author was optimistic about the future trade and investment cooperation between China and Turkmenistan [2]. Cheng Yunjie (2009), in the article "favorable conditions and development prospects of economic and trade cooperation between China and Turkmenistan", believed that there are many favorable conditions for economic cooperation between China and Turkmenistan. The two countries should take good advantage of these favorable conditions and carry out deeper cooperation in energy, tourism, industry and other fields [3]. Yang Yinghua (2008) focused on Turkmenistan's investment policy, investment environment and investment risk in his article "Turkmenistan's investment environment and investment risk", which provided us with an in-depth understanding of Turkmenistan's domestic investment and guidance for other countries to carry out economic cooperation with it [4]. Zhang Long (2012), in his master's thesis "current situation, problems and prospects of natural gas cooperation between China and Turkmenistan", paid attention to the strategic cooperation between China and Turkmenistan in the field of natural gas, analyzed the existing adverse obstacles, and put forward effective measures. The author insisted that it was necessary to carry out energy cooperation between the two countries and that there was a good prospect for development in the future [5]. Zhou Lihua (2012) analyzed the current situation of economic cooperation between China and Turkmenistan in energy, industry, transportation, natural gas and other fields in the paper "Research on the current situation and develop- 
ment trend of trade between China and Turkmenistan", and predicted the development trend of economic and trade exchanges between the two countries in the future, which was of positive practical significance for promoting the strengthening of cooperation between the two countries [6]. In her master's thesis, He Juan (2011) emphasized that energy was the most important resource in Turkmenistan. She analyzed various factors that may affect the cooperation between China and Turkmenistan in the field of energy and concluded [7]. It was believed that China's import of oil and gas to Turkmenistan can maximize its utility and was in the common interests of all parties.

\section{Trade Scale between China and Turkmenistan}

China and Turkmenistan established diplomatic relations on January 6, 1992. The leaders of China and Turkmenistan have close contacts, conducted friendly cooperation in many fields and signed more than 100 bilateral cooperation documents. In April 2006, President Niyazov of Turkmenistan came to China. Through exchanges between the leaders of the two countries, the two sides signed a joint statement. In 2007, President Berdymukhamedov again signed a joint statement with the Chinese government. In November, Chinese Premier Wen Jiabao paid an official visit to Turkmenistan. In May 2014, President Bill Muhamidoff signed the Sino Turkmenistan Treaty of friendship and cooperation with Chinese leaders. This treaty provided protection for further development and deepening of China's strategic partnership. In December 2015, Turkmenistan won the 20th anniversary celebration of permanent neutrality. The special envoy of President Xi Jinping and vice president Li Yuanchao attended the two countries' friendly exchanges. Since the establishment of diplomatic relations between China and Turkmenistan, the rapid development of economic and trade cooperation and frequent interaction between governments have laid a good political foundation for the continuous deepening of economic and trade relations between the two countries [8]. The treaty signed during the high-level meeting between the two countries is the policy and legal basis of bilateral trade, which paves the way for bilateral cooperation between the two countries.

On September 14, 2016, according to Turkmenistan neutral news, Turkmenistan's main foreign trade partners are China, Turkmenistan and Iran. Among them, China is Turkmenistan's largest trade partner. From 2013 to 2017, the total import and export volume between Turkmenistan and China increased from US $\$ 8.2$ billion to US $\$ 23.6$ billion, accounting for $25 \%$ of Turkmenistan's foreign trade volume in the same period, of which natural gas export is the main indicator for the growth of Turkmenistan's trade volume. During 2013-2017, the trade surplus between Turkmenistan and China was about US $\$ 4.8$ - 15.6 billion. It is expected that Turkmenistan will also import large-scale mechanical equipment, electrical equipment and its components, steel products and daily necessities from China, and introduce China's mineral resources exploration equipment and technology. 
In recent years, the economic and trade relations between China and Turkmenistan have been developing rapidly, the fields of cooperation have been expanding, and the volume of trade has been increasing year by year. During President Berdymukhamedov's visit to China, both countries expressed that they should cooperate and take positive measures to implement the economic and trade consensus reached by the leaders of the two countries.

\subsection{Scale of Import and Export between China and Turkmenistan}

As shown in Table 1 and Figure 1, during 1978-2012, the total import and export volume and proportion between China and Turkmenistan showed an

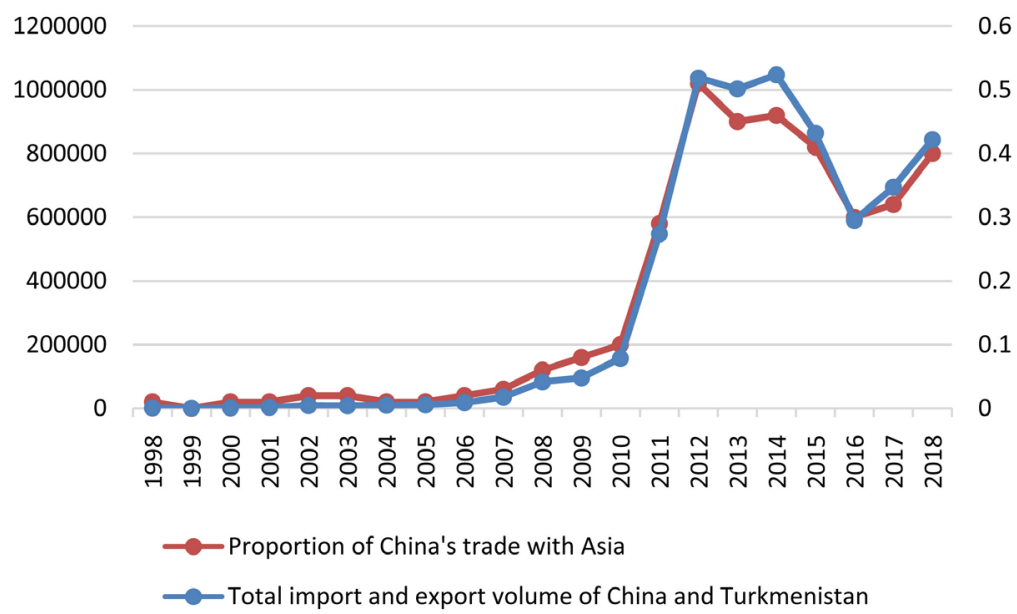

Figure 1. Changes in total import and export volume and proportion between China and Turkmenistan in 1998-2018.

Table 1. Total import and export volume and proportion change between China and Turkmenistan (USD 10,000/\%).

\begin{tabular}{cccccc}
\hline Year & $\begin{array}{c}\text { Total import and } \\
\text { export volume of } \\
\text { China and } \\
\text { Turkmenistan }\end{array}$ & $\begin{array}{c}\text { Proportion } \\
\text { of China's } \\
\text { trade with } \\
\text { Asia }\end{array}$ & Year & $\begin{array}{c}\text { Total import and } \\
\text { export volume of } \\
\text { China and } \\
\text { Turkmenistan }\end{array}$ & $\begin{array}{c}\text { Proportion } \\
\text { of China's } \\
\text { trade with } \\
\text { Asia }\end{array}$ \\
\hline 1998 & 1251 & 0.01 & 2009 & 95,744 & 0.08 \\
1999 & 949 & 0.00 & 2010 & 156,964 & 0.10 \\
2000 & 1616 & 0.01 & 2011 & 547,734 & 0.29 \\
2001 & 3271 & 0.01 & 2012 & $1,037,250$ & 0.51 \\
2002 & 8752 & 0.02 & 2013 & $1,003,090$ & 0.45 \\
2003 & 8292 & 0.02 & 2014 & $1,047,044$ & 0.46 \\
2004 & 9844 & 0.01 & 2015 & 864,313 & 0.41 \\
2005 & 10,996 & 0.01 & 2016 & 590,177 & 0.30 \\
2006 & 17,858 & 0.02 & 2017 & 694,520 & 0.32 \\
2007 & 35,268 & 0.03 & 2018 & 843,651 & 0.40 \\
2008 & 83,038 & 0.06 & & & \\
\hline
\end{tabular}


upward trend; after 2013, the total import and export volume and proportion between China and Turkmenistan showed a downward trend. Specifically, in 1998, China's total import and export trade with Turkmenistan amounted to 12.51 million US dollars, increased to 10.03 billion US dollars in 2012, and then continued to decline to 5.9 billion US dollars in 2016. In terms of the proportion of the total import and export trade between China and Turkmenistan to the total import and export trade between China and Asia, the proportion was $0.01 \%$ in 1998 , increased by $0.51 \%$ in 2012 , and then decreased continuously, to $0.3 \%$ in 2016 [9].

\subsection{Export Scale of China to Turkmenistan}

From 1998 to 2018, the total and proportion of exports between China and Turkmenistan fluctuated greatly. Read Table 2 and Figure 2. From 1998 to

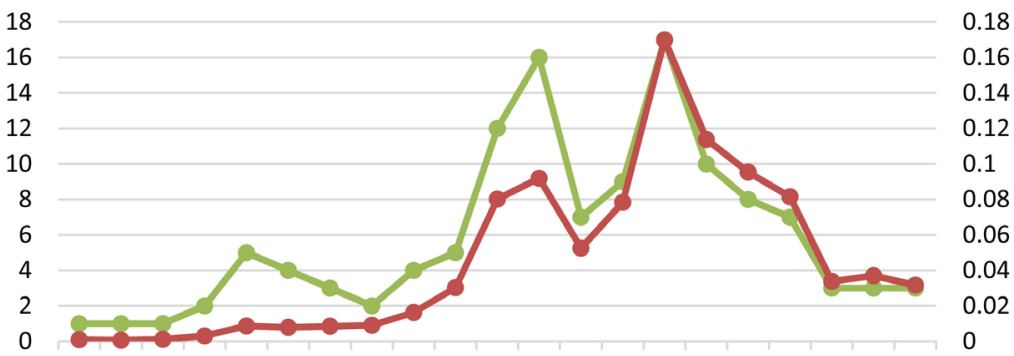

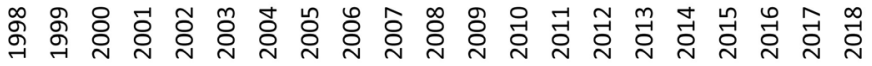

- The proportion of China's total exports to Turkmenistan in China's exports to Asia

- Total exports from China to Turkmenistan

Figure 2. Total exports from China to Turkmenistan.

Table 2. Total export volume of China to Turkmenistan (US \$100 million/\%).

\begin{tabular}{|c|c|c|c|c|c|}
\hline Year & $\begin{array}{c}\text { Total exports } \\
\text { from China } \\
\text { to } \\
\text { Turkmenistan }\end{array}$ & $\begin{array}{l}\text { The proportion of } \\
\text { China's total exports } \\
\text { to Turkmenistan in } \\
\text { China's exports to Asia }\end{array}$ & Year & $\begin{array}{l}\text { Total exports } \\
\text { from China } \\
\text { to } \\
\text { Turkmenistan }\end{array}$ & $\begin{array}{l}\text { The proportion of } \\
\text { China's total exports } \\
\text { to Turkmenistan in } \\
\text { China's exports to Asia }\end{array}$ \\
\hline 1998 & 0.1 & 0.01 & 2009 & 9.19 & 0.16 \\
\hline 1999 & 0.07 & 0.01 & 2010 & 5.25 & 0.07 \\
\hline 2000 & 0.12 & 0.01 & 2011 & 7.84 & 0.09 \\
\hline 2001 & 0.31 & 0.02 & 2012 & 16.99 & 0.17 \\
\hline 2002 & 0.87 & 0.05 & 2013 & 11.38 & 0.10 \\
\hline 2003 & 0.79 & 0.04 & 2014 & 9.54 & 0.08 \\
\hline 2004 & 0.85 & 0.03 & 2015 & 8.15 & 0.07 \\
\hline 2005 & 0.91 & 0.02 & 2016 & 3.38 & 0.03 \\
\hline 2006 & 1.63 & 0.04 & 2017 & 3.7 & 0.03 \\
\hline 2007 & 3.03 & 0.05 & 2018 & 3.17 & 0.03 \\
\hline 2008 & 8.02 & 0.12 & & & \\
\hline
\end{tabular}


2009, the total and proportion of China's exports to Turkmenistan showed a rapid upward trend; after 2009, the total and proportion of China's exports to Turkmenistan showed a downward trend; from 2010 to 2011, it showed an upward trend; after 2012, it showed a rapid downward trend. Specifically, China's total export volume to Turkmenistan in 1998 was US \$100 million, reaching the highest level in 2012, with an export volume of US \$1699 million. In terms of proportion, in 1998, the total import and export trade between China and Turkmenistan accounted for $0.01 \%$ of the total import and export trade between China and Asia, and in 2012, the proportion increased by $0.51 \%$, and then continued to decline, falling to $0.3 \%$ in 2016 .

\subsection{Import Scale of China from Turkmenistan}

From 1998 to 2009, the total and proportion of China's imports from Turkmenistan changed little. As shown in Table 3 and Figure 3, from 2009 to 2014,

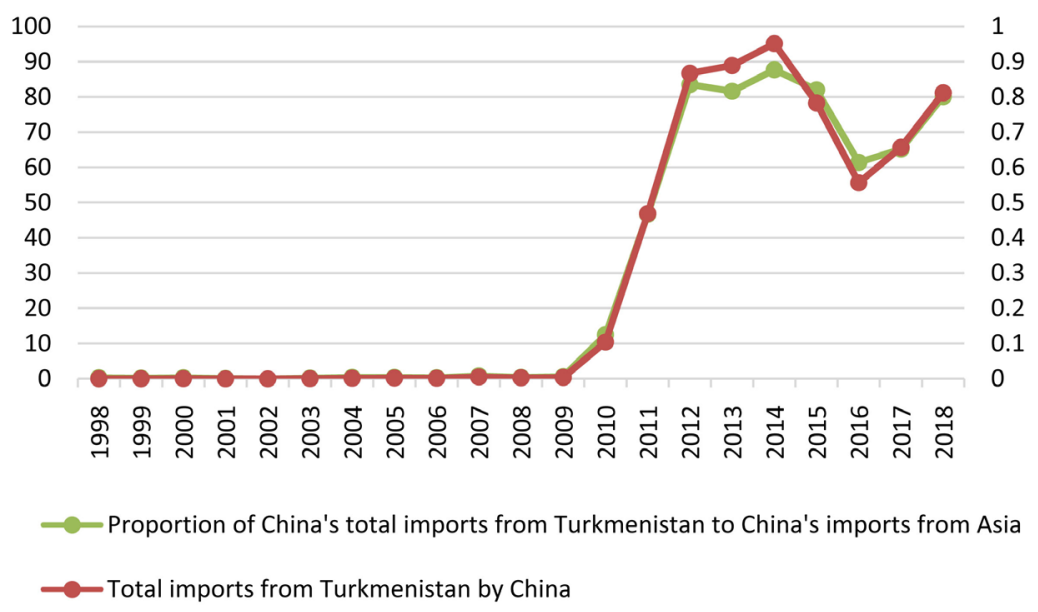

Figure 3. Total imports of China from Turkmenistan.

Table 3. Total import volume of China from Turkmenistan (US \$100 million/\%).

\begin{tabular}{cccccc}
\hline Year & $\begin{array}{c}\text { Total imports } \\
\text { from } \\
\text { Turkmenistan } \\
\text { by China }\end{array}$ & $\begin{array}{c}\text { Proportion of China's } \\
\text { total imports from } \\
\text { Turkmenistan to China's } \\
\text { imports from Asia }\end{array}$ & Year & $\begin{array}{c}\text { Total imports } \\
\text { from } \\
\text { Turkmenistan } \\
\text { by China }\end{array}$ & $\begin{array}{c}\text { Proportion of China's } \\
\text { total imports from } \\
\text { Turkmenistan to China's } \\
\text { imports from Asia }\end{array}$ \\
\hline 1998 & 0.0222 & 0.003 & 2009 & 0.3873 & 0.006 \\
1999 & 0.0202 & 0.002 & 2010 & 10.4452 & 0.125 \\
2000 & 0.0406 & 0.003 & 2011 & 46.9317 & 0.467 \\
2001 & 0.0122 & 0.001 & 2012 & 86.7338 & 0.835 \\
2002 & 0.0074 & 0.000 & 2013 & 88.9326 & 0.816 \\
2003 & 0.041 & 0.002 & 2014 & 95.1616 & 0.877 \\
2004 & 0.1389 & 0.004 & 2015 & 78.2766 & 0.82 \\
2005 & 0.1908 & 0.004 & 2016 & 55.633 & 0.614 \\
2006 & 0.1601 & 0.003 & 2017 & 65.7 & 0.652 \\
2007 & 0.5014 & 0.008 & 2018 & 81.19 & 0.801 \\
2008 & 0.2844 & 0.004 & & & \\
\hline
\end{tabular}


the total and proportion of China's imports from Turkmenistan showed a rapid upward trend; after 2014, the total and proportion of China's imports from Turkmenistan showed a downward trend. Specifically, China's total imports from Turkmenistan in 1998 were only US $\$ 02$ million, which increased to US $\$ 9.516$ billion in 2014, and then decreased to US $\$ 5.563$ billion in 2016. In terms of proportion, China's total imports from Turkmenistan accounted for $0.003 \%$ of China's total imports from Asia in 1998, which increased by $0.877 \%$ in 2014 and decreased by $0.614 \%$ in 2016 .

\section{Trade Structure between China and Turkmenistan}

\subsection{Export Structure of China to Turkmenistan}

The main commodity categories of China's exports to Turkmenistan are: light industrial products account for $29.8 \%$ (including textiles 6.9\%), Footwear 6.7\%, chemical fiber $5.5 \%$, leather products $3.8 \%$, knitwear $3.7 \%$, down products $2.6 \%$, special cloth $0.4 \%$, headgear $0.2 \%$ ); mechanical equipment $19 \%$; means of transport 11.8\%; electrical appliances $11.3 \%$; household products $9.7 \%$; metal and metal products $7.4 \%$ (including steel $5.3 \%$ ); chemical products $3.7 \%$; building materials $3.6 \%$; tea $2.1 \%$; fossil fuel $0.6 \%$; drugs and other $1 \%$.

\subsection{Import Structure of China from Turkmenistan}

China's main import commodities from Turkmenistan are: agricultural products $75.8 \%$ (including various kinds of wool $21.6 \%$, hides $20.7 \%$, licorice $18.1 \%$, cotton linter and waste $10.2 \%$, silk $4.7 \%$, other $0.5 \%$ ); textile products and light industry Products $21 \%$ (including cotton and felt $16.5 \%$, cotton and cotton yarn $3.5 \%)$; iodine $4.2 \%$.

\subsection{Characteristics of Trade Structure between China and Turkmenistan}

First, the volume of trade between China and Turkmenistan has increased substantially. In the past 20 years, China Turkmenistan trade has developed rapidly. From the above analysis, we can see that the data has doubled. The main reason is that China's inland market has significantly increased the scale of imports from Turkmenistan.

Second, China's trade with Turkmenistan covers a wide range of products with rapid growth in scale, but at a lower level and with less added value. From the comparison of trade structure between China and Turkmenistan, it can be concluded that the export scale of China to Turkmenistan is growing rapidly, the scope is wide, and the structure is relatively balanced. However, most of the trade goods of the two countries are labor-intensive products with little added value, and the competitive advantage of China's goods is not obvious.

Third, the possibility of trade complementarity between the two countries has increased. Due to the differences of factor endowment, economic development mode and economic growth level between the two countries, the complementar- 
ity of commodity trade structure is very obvious. China's economic development, an urgent problem is the energy problem, the market demand is huge, but it does not have enough output, so it is imperative to expand the import channels to ensure the supply and stability of the domestic market, as well as the national energy security. As one of the neighboring Central Asian countries rich in oil and gas resources, Turkmenistan is bound to become one of China's indispensable partners. In recent years, China has become the largest export market of Turkmenistan's natural gas [10]. The continuous supply of oil and gas has made Turkmenistan's GDP keep rising. The stable and huge market income has ushered in a new historical development opportunity for Turkmenistan after independence. Moreover, in a certain period of time, Turkmenistan will continue to rely on China's market, capital, technology and talents.

\section{Problems in China Turkmenistan Economic and Trade Cooperation}

\subsection{Imperfect System and Policy}

Both China and Turkmenistan have big problems in policy and system. China's authorities have not strictly regulated the export of goods, resulting in the export of many substandard products to Turkmenistan. The biggest advantage of Chinese products is good quality and low price. However, due to the uneven quality of products exported to Turkmenistan, Turkmenistan people have a negative impression of "made in China". Moreover, some Turkmen businessmen who are seeking huge profits import some products with low cost and poor quality, and then sell them to the Turkmen people at a high price, which puts "made in China" in worse situation. Many Turkmen people are no longer willing to consume Chinese products. Although this phenomenon was especially serious in the early stage of China Turkmenistan trade and has been improved, the negative impact caused by this problem is still far-reaching.

Similarly, the import policies of Turkmenistan are not sound. Although the economic and trade cooperation between China and Turkmenistan is booming and the trade volume is increasing year by year, there is still no perfect import policy. As a result, the import approval procedures of Chinese goods are cumbersome, time-consuming and expensive. This problem either causes the goods to be overstocked in the port or the border, or makes some businessmen have no choice but to choose "grey customs clearance". Either situation will have a negative impact on China Turkmenistan trade cooperation.

\subsection{Trade Imbalance between China and Turkmenistan}

Due to the great difference in economic strength between China and Turkmenistan, and the great difference in the import and export commodity structure between the two countries, most of the products China imports into Turkmenistan are cotton, energy, non-ferrous metals, etc., while the products China exports to Turkmenistan are heavy machinery, communication products, machi- 
nery and equipment, etc., which leads to the extremely unbalanced trade between the two countries. Most of the time, China has a trade surplus, while Turkmenistan has a trade deficit. Although the trade gap between the two countries has been alleviated by the in-depth cooperation in the fields of natural gas, oil and other energy in recent years, he overall strength of the trade between the two countries is still very different. The trade imbalance between China and Turkmenistan will lead to the aggravation of exchange rate risk, the aggravation of bilateral economic and trade frictions, the exclusion of Turkmenistan people from Chinese products, and the deterioration of trade terms. If this situation continues, it will inevitably have a negative impact on the healthy economic development of the two countries, and seriously hinder the normal development of bilateral trade between China and Turkmenistan.

\subsection{Industrial Protection Measures in Turkmenistan}

Price is undoubtedly the biggest trade advantage of China's light industrial products. Because of its low price and good quality, it is favored by consumers all over the world, and the people of Turkmenistan are no exception. As time goes on, Turkmenistan's local enterprises will lose their market competitiveness, and may eventually go bankrupt because their products are not popular. Obviously, this is extremely detrimental to the growth of domestic industry in Turkmenistan. For example, the carpet produced in Turkmenistan has a high labor cost because it is purely handmade. The market price of a piece of $2 \times 2$ carpet is $5000-6000$ yuan, while the carpet produced in China has a relatively low cost because it is machine-made, and the quality is almost the same as that produced in Turkmenistan, but the market price is only $1 / 5$ or even lower than that of the carpet produced in Turkmenistan. This phenomenon has aroused the vigilance of the relevant authorities of Turkmenistan. In order to avoid this phenomenon and protect the development of traditional industries and the interests of entrepreneurs, strict import policies have been formulated for some products. To some extent, the implementation of this policy has restrained the diversification of China Turkmenistan trade.

\subsection{Exchange-Rate Risks}

Exchange rate risk is a very prominent problem in China Turkmenistan bilateral trade. Because the trade between China and Turkmenistan is denominated in US dollars, the trade between the two countries is vulnerable to the fluctuation of US dollar exchange rate. At present, the US dollar is declining relative to the RMB. For Chinese export enterprises, the appreciation of the RMB and the depreciation of the US dollar will reduce the foreign exchange income of Chinese export enterprises. On the contrary, Turkmenistan carried out the monetary system reform in 2008, which made manta and the US dollar maintain a fixed exchange rate, so the import and export trade enterprises of Turkmenistan will not be affected by the exchange rate risk. Therefore, China's export enterprises are the most vulnerable to exchange rate risk in China Turkmenistan trade. 
When the US dollar depreciates, they tend to reduce their exports to Turkmenistan. Of course, the exchange rate change is also a double-edged sword. On the one hand, the depreciation of the US dollar will reduce the foreign exchange income of Chinese export enterprises, but on the other hand, it will also reduce the cost of China's import to Turkmenistan, and the RMB to be paid will be reduced. In any case, exchange rate risk is a key issue in the trade between the two countries. If it is serious, it will cause immeasurable damage to the trade between the two countries. This issue deserves the attention of both governments.

\section{Suggestions on China Turkmenistan Economic and Trade Cooperation}

\subsection{Improve Corresponding Policies and Systems}

China should strengthen the supervision and management of the quality of export commodities, and issue corresponding standards to standardize the quality of export products. And this kind of standard should be consistent in all exporting countries. We should not reduce the quality and technical standards because it is a third world country. The products exported from one country to other countries represent the image of the country. If the quality is poor, it will affect the impression of the people of the importing country on the products of the exporting country, and eventually lead to the crisis of trade cooperation between the two countries. Therefore, strict quality control of export products is of far-reaching significance for bilateral trade cooperation. China's Ministry of commerce should implement the end elimination system, conduct spot check on the quality of export products, and cancel the foreign trade operation right of the enterprises at the end according to the results of the spot check, so as to ensure the quality of export products to a certain extent, which is conducive to the healthy competition of foreign trade enterprises. It is also necessary for Turkmenistan to improve the policies and procedures for the import of foreign products, simplify the examination and approval procedures, shorten the time and improve the efficiency, and set up special agencies to be responsible for the operation and management of the import and export of commodities.

\subsection{Relax the Protection Measures of Turkmenistan to the Industry}

In order to protect the healthy development of its traditional industry, it is understandable that Turkmenistan has implemented strict control measures on the import of certain commodities. However, in the long run, it will inevitably dampen the enthusiasm of foreign investors to invest in Turkmenistan, leading to the plight of Turkmenistan's foreign trade. Therefore, the government of Turkmenistan should appropriately reduce the threshold for foreign commodities to enter the industry, so that there will be benign competition in the industry, the survival of the fittest, and it will greatly improve the efficiency of resource allocation, so that enterprises with good development potential can obtain more resources, while enterprises that do not conform to the market rules 
will be eliminated naturally. If we insist on the cultivation of our traditional industries in the greenhouse, the enterprises in this industry will be satisfied that they will not strive to improve their products, increase the added value of products and create greater economic profits, which will actually pose a huge threat to our industry. Therefore, the Turkmenistan government should appropriately relax the protection of its own industry, create a certain competitive environment, and always believe that only continuous competition can promote development.

\subsection{Create a More Ideal Investment Environment}

The government of Turkmenistan has made great efforts to attract foreign investment to improve its economic strength and achieve stable growth of trade volume. Turkmenistan is also a hot investment spot for many foreign investors, mainly due to its rich oil and gas reserves, but the degree of exploration is low, with great development potential. Although the political environment in Turkmenistan is relatively stable, and the government has formulated relevant preferential policies to encourage foreign investment. However, the investment environment of Turkmenistan still has many disadvantages, such as backward infrastructure construction; located in the hinterland of Central Asia, $60 \%$ of the land is desert; backward national management system and so on. These factors will undoubtedly make Chinese investors take a more comprehensive consideration when they invest in Turkmenistan, and to a certain extent reduce the enthusiasm of Chinese investors. Therefore, in order to reduce the investment risk, the relevant organizations of Turkmenistan should first improve the infrastructure construction, improve the transportation construction, and create convenient conditions for Chinese investors; secondly, reform the domestic political system to adapt to the market economy; finally, vigorously develop the service industry related to the energy industry, so as to obtain great benefits for foreign investors when they invest in the energy industry convenience. Of course, Chinese investors should also seize the opportunity to take effective market strategies while avoiding risks as much as possible, and carry out friendly cooperation with Turkmenistan with the energy sector as the core.

\subsection{Effectively Prevent the Exchange Rate Risk of China Turkmenistan Trade}

It is the root cause of the exchange rate risk that the US dollar is used in the valuation and settlement of China Turkmenistan trade. In order to effectively prevent the exchange rate risk in the trade between the two countries, the two countries should try to reduce the valuation and settlement of US dollars, and increase the valuation and settlement of RMB or man at currency. If we have to use US dollar, Chinese export enterprises can use trade strategy and financial strategy to minimize the harm caused by US dollar exchange rate risk. There is a price adjustment method in the trade strategy, i.e. to raise the price of China's exports to the Turkmenistan countries or to balance the elimination method. 
That is, after Chinese enterprises have priced their exports to the Turkmenistan countries in US dollars, they will arrange another commodity priced in US dollars with the same amount to be imported from the Turkmenistan countries to China, so that the import and export balance will be automatically balanced. The main financial strategies that can be adopted are foreign exchange trading method, insurance method and LSI or BSI. Through the joint action of the above methods, we can effectively alleviate the exchange rate risk encountered in bilateral trade between China and Turkmenistan, and create a good investment environment for bilateral economic and trade cooperation.

\section{Conflicts of Interest}

The authors declare no conflicts of interest regarding the publication of this paper.

\section{References}

[1] Repkine, A. (2004) Turkmenistan: Economic Autocracy and Recent Growth Performance. The Economic Prospects of the CIS, Sources of Long Term Growth. Edward Elgar, Cheltenham, UK and Northampton, MA, 154-176. https://doi.org/10.4337/9781845420567.00013

[2] Zhao, Q.S. (2013) History, Current Situation and Prospect of Economic and Trade Cooperation between China and Turkmenistan. Xinjiang Finance and Economics, No. 6, 64-70.

[3] Cheng, Y.J. (2009) Favorable Conditions and Development Prospects of Economic and Trade Cooperation between China and Turkmenistan. Foreign Trade, No. 4, 35-39.

[4] Yang, Y.H. (2001) Turkmenistan's Investment Environment and Investment Risk. Shandong Taxation, No. 8, 64-65.

[5] Zhang, L. (2012) Current Situation, Problems and Prospects of Natural Gas Cooperation between China and Turkmenistan. Thesis, Xinjiang Normal University, Urumqi.

[6] Zhou, L.H. (2012) Study on the Current Situation and Development Trend of Trade between China and Turkmenistan. International Trade, No. 6, 107-108.

[7] He, J. (2011) Research on Energy Cooperation between China and Turkmenistan. Lanzhou University, Lanzhou.

[8] Wu, H.W. (2011) Trade Relations between China and Five Central Asian Countries. Russia, Central Asia and Eastern Europe Market, No. 6, 1-7.

[9] Saurbek, B. (2012) Bilateral Economic and Trade Relations between Turkmenistan and China and their Prospects. Central China Normal University, Wuhan.

[10] Lanteigne, M. (2007) China's Energy Security and Eurasian Diplomacy: The Case of Turkmenistan. Politics, 27, 147-155. https://doi.org/10.1111/j.1467-9256.2007.00294.x 